\title{
PERAN NEGARA DALAM PENGELOLAAN SUMBER DAYA KELAUTAN BERBASIS KEARIFAN LOKAL UNTUK KESEJAHTERAAN YANG BERKEADILAN
}

\author{
Rachmad Safaat, Dwi Yono \\ Fakultas Hukum Universitas Brawijaya \\ Jl. MT Haryono No. 169 Malang \\ E-mail ; dwi_yono17@yahoo.com
}

\begin{abstract}
Marine and coastal area management is necessary to be operated comprehensively and sustainable. The existence of indigenous peoples and traditional society has a role in the marine and coastal areas management, but the legislation has not been fully giving more protection in its management. Economic base development, generally often ignore local society wisdom, so that a clean environment is being polluted as a result of that waiver. Development that materialistic value oriented, only the physical build that actually provide benefits to investors and not the community itself. What kind of justice that ideally obtained by indigenous and traditional peoples to achieve justice that bring prosperity? The government has neglected and must fix the policies in the legislation as a foundation for development without neglecting the indigenous people themselves. Equitable development not just physically, but sustainable development to preserve nature by observing local society wisdom that have taken place to the next. The government still considered neglectful for environmental management.
\end{abstract}

\section{Keywords: Role of The State, Marine Resources, Local Wisdom}

\begin{abstract}
Abstrak
Pengelolaan wilayah pesisir dan kelautan sangat diperlukan secara menyeluruh dan berkelanjutan. Keberadaan masyarakat adat dan masyarakat tradisional mempunyai peran dalam pengelolaan wilayah pesisir dan kelautan, namun peraturan perundangundangan belum sepenuhnya menberikan perlindungan dalam pengelolaan pesisir. Pembangunan yang berbasiskan ekonomi umumnya sering mengabaikan kearifan lokal masyarakat, sehingga lingkungan yang bersih menjadi tercemar akibat pengabaian tersebut. Pembangunan yang berorientasikan nilai materialistik hanya membangun fisik yang justru memberikan keuntungan bagi penanam modal, bukan masyarakat itu sendiri. Bagaimanakah keadilan yang idelanya didapatkan oleh masyarakat adat dan tradisional untuk mencapai keadilan yang mensejahterakan. Pemerintah abai dan harus membenahi kebijakan dalam perundang-undangan sebagai pijakan melaksanakan pembangunan tanpa mengabaikan masyarakat adat itu sendiri, dan pemerataan pembangunan bukan sekedar pembangunan fisik, melainkan pembangunan yang menjaga kelestarian alam dan berkelanjutan dengan memperhatikan kearifan lokal masyarakat yang sudah berlangsung turun menurun. Pemerintah masih dirasa abai atas pengelolaan lingkungan.
\end{abstract}

Kata Kunci: Peran Negara, Sumber Daya Kelautan, Kearifan Local 


\section{A. PENDAHULUAN}

Keberadaan lautan dan pesisir di Indonesia merupakan suatu anugerah yang besar, dengan potensi kekayaan yang terkandung di dalamnya, potensi yang terdapat di laut baik sumber daya perikanan maupun sumber daya mineral. Terdapat kurang lebih $60 \%$ dari total jumlah penduduk Indonesia yang mendiami wilayah pesisir, dengan lebar $50 \mathrm{Km}$ dari garis pantai. Di kawasan tersebut, terdapat $80 \%$ area industri Indonesia yang beroperasi dan memanfaatkan sumber daya pesisir, dimana dalam proses industrialisasinya melakukan pembuangan limbahnya ke kawasan pesisir. Padahal, merujuk pada data yang ada, sumber daya pesisir merupakan sumber dan pusat biodeversity laut tropis terkaya di dunia, dimana $30 \%$ hutan bakau dunia ada di Indonesia; 30\% terumbu karang dunia ada di Indonesia, 60\% konsumsi protein hewani yang berasal dari sumber daya perikanan, sedangkan $90 \%$ ikan berasal dari perairan pesisir dalam yang berjarak 12 mil laut dari garis pantai. ${ }^{1}$

Indonesia merupakan negara maritim dengan luas total sekira $7.827 .087 \mathrm{Km}^{2}$ yang terletak di zamrud khatulistiwa, daerah pertemuan antara dua samudera, memiliki kekayaan sumber daya alam yang sangat melimpah, khususnya di wilayah laut dan pesisir yang luasnya mencapai $3 / 4$ wilayah Indonesia $\left(5,8 \mathrm{Km}^{2}\right)$. Dilihat dari jumlah pulaunya, Indonesia memiliki jumlah pulau sebanyak 17.504 pulau, merupakan negara pemilik pulau yang terbanyak di dunia. Dengan jumlah pulau sebanyak itu, berdampak pula pada panjang garis pantai Indonesia, yang mencapai $81.000 \mathrm{Km}$, dan merupakan garis pantai terpanjang kedua di dunia setelah Kanada. Luas wilayah perairan $5,8 \mathrm{Km}^{2}$ tersebut, terdiri dari Zona Ekonomi Ekslusif 2,7 juta $\mathrm{Km}^{2}$, perairan kepulauan 2,8 juta $\mathrm{Km}^{2}$, dan Wilayah laut 0,3 juta $\mathrm{Km}^{2}$.

Potensi sumber daya alam yang ada di perariran dan pesisir potensi untuk dieksplorasi dan dimanfaatkan mempunyai nilai yang sangat besar, potensi yang ada untuk dimanfaatkan dan mempunyai nilai ekonomi. Pantai yang ada di wilayah pesisir Indonesia mempunyai manfaat untuk sector pariwisata, namun juga bisa mempunyai potensi sumber daya mineral yang dapat dieksplorasi untuk kepentingan tambang, misalnya minyak bumi, gas bumi dan yang lain. Potensi ini menjadikan daya tarik untuk mendatangkan investor dalam mengelolah sumber daya alam yang ada, dan tentunya akan menjadi fungsi pembangunan yang dianggap membantu pemerintah dalam memeratakan pembangunan.

Pembangunan dan eksplorasi potensi sumber daya alam di wilayah laut dan pesisir ini justru berpeluang merusak lingkungan dan ekosistem lingkungan di tempat maupun sekitarnya, dan juga mengganggu tatanan masyarakat adat yang ada. Di sisi lain masyarakat adat mempunyai kemampuan dalam pengelolaan sumber daya alam yang tersingkirkan oleh pembangunan itu sendiri, sehingga yang awalnya masyarakata dat menjaga lingkungan dan ekosistem dengan peradaban kearifan lokalnya harus tersingkirkan oleh pembangunan.

1 Lihat Rokmin Dahuri, dkk. Pengelolaan Sumberdaya Wilayah Pesisir dan Lautan Secara Terpadu, Pradnya Paramita, 1996, hlm. 1.

2 Fredy Numbery dalam Ruchyat Deni, Bahari Nusantara Untuk Kesejahteraan Masyarakat dan Ketahanan Nasional, (The Media of Social and Cultural Communication (MSCC), Jakarta, 2009), hlm.3 
Keberadaan masyarakat yang mendiami wilayah pesisir, sudah sepantasnya mereka mendapat hak dan dilindungi oleh konstitusi, dimana konstitusi menjamin setiap warga negaranya, termasuk yang tinggal di wilayah pesisir tanpa terkecuali. Keberadaan konstitusi pun mengakui masyarakat adat yang hidup di Indonesia, tertuang dalam Pasal 18B ayat (2) Undang-Undang Dasar Negara Republik Indonesia Tahun 1945 (UUD NRI Tahun 1945) termasuk pula dijamin hak asasinya. ${ }^{3}$ Tentunya, tak terkecuali masyaraat adat yang mendiami wilayah pesisir. Mereka berhak untuk hidup sejahtera dan tinggal dalam lingkungan yang layak.

Pengakuan terhadap masyarakat adat tersebut menjadi dasar eksistensi masyarakat adat agar tetap hidup dan berkembang dengan cara dan tradisi luhurnya yang secara turun temurun mendiami serta bertempat tinggal di suatu tempat, demikian pula dalam aktifitas perekonomian untuk mendapat hak hidupnya. Mereka mengolah sumber daya alam yang ada dengan cara tradisional tanpa merusak alam, mengambil seperlunya kebutuhan dari alam dan sebagainya.

Berawal dari lahirnya Undang-Undang Nomor 27 Tahun 2007 tentang Pengelolaan Wilayah Pesisir dan Pulau-Pulau Kecil (Selanjutnya disebut UU No. 27 Th. 2007) yang tujuannya mengatur pengelolaan dan pembangunan wilayah pesisir dan pulau-pulau kecil, yang mana aturan dalam UU tersebut ternyata tidak sesuai dengan semangat konstitusi. Akan tetapi UU ini telah mengalami perubahan akibat telah dilakukan judicial review ke Mahkamah Konstitusi karena dianggap ada beberapa ketentuan di dalamnya yang bertentangan dengan konstitusi.

Keberadaan UU No. 27 Th. 2007 yang dimana dalam penerapannya menindas dan mematikan bahkan mencabut hak hidup masyarakat adat dan juga masyarakat di pesisir yang sudah menetap dengan pola dan tata cara untuk mengelolah, memenuhi kebutuhannya dan bertempat tinggal dengan cara melestarikan kebudayaan dan kearifan lokalnya.

Dilakukan revisi terhadap UU No 27 Tahun 2007 akibat beberapa pasal yang dibatalkan oleh Mahkamah Konstitusi melalui amar putusannya Nomor 3/PUU-VIII/2010 yang kemudian dilahirkan UU No. 1 Tahun 2014 tentang Perubahan UU No 27 Tahun 2007, yang dalam UU No. 1 Tahun 2014 pengaturan pemanfaatan untuk masyarakat adat diberlakukan secara bersyarat, dimana syarat tersebut masih "semu."

Keberadaan masyarakat adat bukanlah keadaan yang primitif melainkan keadaan yang masih menjaga kearifan lokal dimana kehidupan yang serasi dengan alam melalui kegiatan yang masih menjaga kelestarian lingkungan atau menjaga keseimbangan ekosistem alam dengan cara alami bukan melalui sentuhan teknologi modern.

Berangkat dari uraian yang sudah ada di atas, menjadi pertanyaan yang akan dikaji, bagaimana peran negara dalam melakukan pengelolaan sumber daya kelautan, terutama dalam

${ }^{3}$ Ibid. 
menjaga keseimbangan pembangunan dan keberadaan masyarakat adat di wilayah pesisir dengan segala bentuk potensi kearifan lokalnya.

\section{B. PEMBAHASAN}

\section{Politik Hukum Pembangunan Kelautan}

Pembangunan Indonesia yang merupakan cita bangsa dapat dimaknai sebagai upaya untuk memakmurkan dan mensejahterakan rakyatnya, sehingga hal itu mutlak diperlukan. Namun, pembangunan yang terjadi terkadang justru tidak berpihak kepada kemakmuran dan kesejahteraan rakyat itu sendiri. Sesuai bentuk yang telah disepakati sebelumnya, Indonesia merupakan negara hukum, sehingga kebijakan yang dilakukan pemerintah haruslah berdasarkan ketentuan norma hukum, atau bisa disebut juga berdasarkan peraturan perundang-undangan yang merupakan hasil dari politik hukum, sedangkan bentuk perundang-undangan tersebut adalah bentuk politik perundang-undangan.

Satjipto Rahardjo menyebutkan eksistensi negara hukum (rechstsstaat) Republik Indonesia sebagaimana tersirat dalam pembukaan UUD 1945 adalah mengarah kepada kebahagiaan manusia in casu rakyat Indonesia. ${ }^{4}$ Oleh karena itu menjadi tugas negara dalam hal ini pemerintah adalah mengimplementasikan amanat alinea kedua dan keempat Pembukaan UUD 1945 dalam peraturan perundangan-undangan. Pemerintah harus cermat melihat pesan moral dibalik UUD $1945 .^{5}$

Pembangunan mempunyai masa yang berbeda, dan ini pengaruh dari politik hukum pada masa pemerintahan yang berkuasa. ${ }^{6}$ Tujuan pembangunan pemerintahan Indonesia sejak tahun 1950-an berorientasi pada pembangunan sektor pertanian, seperti yang ditulis oleh Rachmad Safa'at mengenai fase pembangunan pedesaan dari era tahun 1950-an yang dimulai dengan penekanan pembangunan komunitas pertumbuhan usaha tani kecil, menginjak 1960-an pertumbuhan usaha kecil tani yang dilanjutkan upaya pembangunan pedesaan terintegrasi yakni melalui kebijakan transfer teknologi, mekanisasi dan penyuluhan pertanian, 1970-an menuju liberalisasi pasar dan 1980-an penyusaian struktural dan pasar bebas. ${ }^{7}$ Pada tahun 1985 Indonesia berhasil swasembada pangan dan mendapat penghargaan dari FAO dan kemudian awal 1990-an pemerintah Indonesia berusaha menjadi negara industri hingga berakhirnya rejim Pemerintahan Soeharto.

Politik kekuasaan berganti dan pada era Presiden Abdurachman Wachid pembangunan sektor kelautan mulai dilakukan hal ini terwujudkan dengan adanya kementerian kelautan dan perikanan kali pertama yang digagas oleh Presiden

4 Lihat Rachmad Safa'at Loc., cit Rekonstruksi Politik... mengutip Satjipto Rahadjo, Mendudukan UndangUndang Dasar, Suatu Pembahasan Dari Optik Ilmu Hukum Umum, Badan Penerbit Universitas Diponegoro, Semarang, 2007

Ibid

Ibid

Ibid., hlm. 150 
Abdurachman Wachid. Presiden Abdurrahman Wahid dengan Keputusan Presiden No.355/M Tahun 1999 tanggal 26 Oktober 1999 dalam Kabinet Periode 1999-2004 mengangkat Ir. Sarwono Kusumaatmaja sebagai Menteri Eksplorasi Laut, yang kemudian dari Kepres No. 355/M Tahun 1999. Selanjutnya pengangkatan tersebut diikuti dengan pembentukan Departemen Eksplorasi Laut (DEL) beserta rincian tugas dan fungsinya melalui Keputusan Presiden Nomor 136 Tahun 1999 tanggal 10 November 1999 tentang Kedudukan, Tugas, Fungsi, Susunan Organisasi, dan Tata Kerja Departemen. Ternyata penggunaan nomenklatur DEL tidak berlangsung lama karena berdasarkan usulan DPR dan berbagai pihak, telah dilakukan perubahan penyebutan dari Menteri Eksplorasi Laut menjadi Menteri Eksplorasi Laut dan Perikanan berdasarkan Keputusan Presiden Nomor 145 Tahun 1999 tanggal 1 Desember 1999. Perubahan ini ditindaklanjuti dengan penggantian nomenklatur DEL menjadi Departemen Eksplorasi Laut dan Perikanan (DELP) melalui Keputusan Presiden Nomor 147 Tahun 1999 tanggal 1 Desember 1999.

Dalam perkembangan selanjutnya, telah terjadi perombakan susunan kabinet setelah Sidang Tahunan MPR tahun 2000, dan terjadi perubahan nomenklatur DELP menjadi Departemen Kelautan dan Perikanan (DKP) sesuai Keputusan Presiden Nomor 165 Tahun 2000 tanggal 23 November 2000 tentang Kedudukan, Tugas, Fungsi, Wewenang, Susunan Organisasi, dan Tata Kerja Departemen. ${ }^{8}$

Paradigma pembangunan di sektor kelautan pada dasarnya mendapatkan perhatian yang cukup serius oleh pemerintahan era Jokowi, hingga untuk pertama kalinya, Indonesia memiliki Menteri Koordinator Maritim dan Sumber Daya Kelautan. Politik hukum yang dicita-citakan pemerintahan saat ini adalah pembangunan kelautan, tanpa meninggalkan pembangunan di sektor lainnya. ${ }^{9}$ Kebijakan yang cukup populer misalnya terkait tol laut, pengeboman kapal asing pencuri kekayaan laut di wilayah Indonesia dan sejenisnya.

Pembangunan wilayah pesisir mencerminkan adanya politik hukum pemerintahan untuk melakukan pengelolaan melalui pendekatan Pengelolaan Wilayah Pesisir Terpadu (Integrated Coastad Management) dengan tujuan untuk penguatan dan sinergi pembangunan wilayah pesisir di tingkatan pemerintahan maupun berbagai sektor lain di tingkat legislasi, sehingga pembangunan sektor ekonomi dengan pelestarian wilayah pesisir memperhatikan karakteristik dan keunikan setiap wilayah. Pengelolaan dan perlindungan terhadap hak-hak masyarakat wilayah pesisir maupun hak masyakat adat. ${ }^{10}$ Pemerintah juga telah menerbitkan aturan yang menjadi landasan hukum pengelolaan wilayah pesisir melalui Peraturan Presiden Nomor 73 Tahun 2015 tentang Pelaksanaan

8 Sejarah Terbentuknya Kementerian Kelautan dan Perikanan (KKP) Lihat <http://kkp.go.id/index.php/sejarah-terbentuknya-kementrian-kelautan-dan-perikanan-kkp/ > diakses 8 Agustus 2015

Ibid.

${ }^{10}$ Lihat Amiruddin A. Dajaan Imami, Hukum Penataan Ruang Kawasan Pesisir, Harmonisasi dalam Pembangunan Berkelanjutan, Logoz Publishing, Bogor, 2014, hlm 35-38 
Koordinasi Pengelolaan Wilayah Pesisir dan Pulau-Pulau Kecil Tingkat Nasional yang bertujuan untuk mengkoordinasikan pengelolaan wilayah pesisir Indonesia.

Politik hukum pembangunan wilayah pesisir masih berbasiskan pembangunan sektor ekonomi yang diutamakan hingga produk hukum yang dihasilkan sebagai bentuk politik perundang-undangan yakni UU No 27 Th 2007 mengalami revisi yang kemudian semangat pembangunan yang ada pada perubahan UU No 27 Th 2007 menjadi pembangunan yang berbasiskan pembanguan wilayah pesisir terpadu dengan adanya UU No. 1 Th 2014 salah satunya adalah bentuk pengakuan hak masyarakat tradisional dan masyarakat adat yang hak dan kewajibannya dijamin oleh pemerintah melalui paying hukum.

Hukum yang baik, selain responsif juga harus memberikan keadilan, karena ruh dari hukum adalah keadilan, seperti dalam penggalan Al Qur'an surat An Nisa ayat $58^{11}$ wa idzaa hakamtum bainan naasi an tahkumuu bil 'adl(i) yang artinya

"Dan apabila kamu menetapkan hukum di antara manusia supaya kamu menetapkan dengan adil”

Dalam ayat ini didahului amanah agar tersampaikan, dalam memberikan keadilan dan membuat hukum terdapat amanah di dalamnya, yakni memberikan kepastian, keadilan, perlindungan yang melekat di dalamnya. Untuk itu pembuat hukum hendaklah mempunyai pengetahuan dalam membuat peraturan perundang-undangan, agar subtansi dari pasal demi pasal memberikan perlindungan dan kepastian bagi masyarakat, terutama bagi masyarakat adat.

Qur'an Surat An Nisa Ayat 58 memerintahkan dalam menunaikan amanah, ditekankannya bahwa amanah tersebut harus ditunaikan kepada ahlihaa yakni pemiliknya, dan ketika memerintahkan menetapkan hukum secara adil, dinyatakannya apabila kamu menetapkan hukum di antara manusia. Ini berarti bahwa perintah berlaku adil itu ditunjukkan terhadap manusia secara keseluruhan. Dengan demikian, baik amanah maupun keadilan harus ditunaikan dan ditegakkan tanpa membedakan agama, keturunan, atau ras. ${ }^{12}$

Negara dan agama mempunyai hubungan yang sangat dekat seperti yang disampaikan oleh Imam Ghazali bahwa Al-ddin wal mulku tau'amani faddin ashlun was sulthanu haarisun (agama dan Negara itu saudara kembar, agama sebagai pondasi dan pemimpin sebagai penjaga). Seyogyanya, kita berpijak pada piagam Madinah yang dibuat oleh Nabi Muhammad SAW dalam menyusun suatu tata aturan bermasyarakat, berbangsa dan bernegara. Isinya antara lain adalah Al-ukhuwah bainal muslimin (persaudaraan di antara umat islam), dan terhadap masyarakat di luar Islam yang berbeda secara aqidah dan syari'ah kita nyatakan lakum dinukum waliyadin (untukmu agamamu dan untukkulah agamaku), serta seluruh elemen masyarakat (baik agama, suku, dan golongan) yang ada

11 Lihat AL Quran dan terjemahan Surat An Nisa ayat 58

12 Lihat M. Quraish Shihab, Tafsir Al Misbah Volume 2, Lentera Hati, Jakarta, 2002, hlm. 580-582 
di Madinah harus saling tolong menolong dan harus mempertahankan Negara dari serangan pihak luar. Jadi religiusitas dan nasionalisme harus menjadi pijakan dalam berbangsa dan bernegara. ${ }^{13}$

\section{Kedudukan Masyarakat Adat}

Sebelum memulai pembahasan, kita mulai dengan mencari pengertian atau mengetahui apa yang disebut masyarakat adat terlebih dahulu. Dalam bahasa perundangundangan lebih sering disebut dengan "masyarakat hukum adat", mulai dari hukum tertinggi atau konstitusi menyebutkannya sebagai "masyarakat hukum adat". ${ }^{14}$

Dalam berbagai peraturan perundang-undangan penyebutan istilah "masyarakat hukum adat" banyak dipakai istilah "masyarakat hukum adat", misalnya pada UU No. 5 Tahun 1960 tentang Peraturan Dasar Pokok-Pokok Agraria, UU No. 41 Tahun 1999, UU No. 18 Tahun 2004 tentang Perkebunan, UU No. 32 Tahun 2009 tentang Pengelolaan Lingkungan Hidup, UU No. 1 Tahun 2014 tentang Perubahan UU No. 27 Tahun 2007 tentang Pengelolaan Pesisir dan Pulau-pulau Kecil ${ }^{15}$ dan beberapa undang-undang lainnya serta sejumlah peraturan pelaksana dari undang-undang.

Kedudukan masyakarat dalam literature perundang-undangan belum menyentuh bagaian subtansi masyarakat adat itu sendiri, pembentuk undang-undang menempaktakan masyarakat adat dalam kententuan umum yang mengatur pengertian-pengertian dalam perundang-undang itu sendiri, sedangkan masyakat adat itu sendiri tidak masuk dalam subtansi yang mengatur keberadaan sebagai subjek, bahkan undang-undangan mengenai masyakat adat sendiri pun belum terakomodir hingga saat ini.

Peter Burns ${ }^{16}$ menyebutkan bahwa sejarah penggunaan istilah "hukum adat" (adatrecht) bermula dan digagas oleh Mahzab Leiden, mereka cenderung mengartikan adat sebagai hukum (recht). Gagasan yang dicetuskan oleh Cornelis Van Vollenhoven tersebut, memahami adat dan hukum adat (adatrecht) sebagai manifestasi dari pandangan hidup khas Indonesia yang asing bagi cara berfikir orang Eropa, teruama bagi orang Belanda. $^{17}$

Hukum adat yang dibuat oleh masyarakat itu sendiri, sengaja dibuat untuk menciptakan ketertiban hukum atau perilaku manusia, meliputi perbuatan manusia

13 Baca Peranan Agama, Negara dan Budaya dalam Membangun Bangsa <http://www.siagaindonesia.com/2015/03/peranan-agama-negara-dan-budaya-dalam-membangun-bangsa>

14 Lihat Pasal 18B UUD NRI Tahun 1945

15 Sebelumnua pada UU No 27 Tahun 2007 tidak menyebut masyarakat hukum adat, melainkan masyarakat adat yang didalam Ketentuan Umum Pasal 1 angka 33, Masyarakat adat adalah kelompok masyarakat pesisir yang secara turun-temurun bermukim di wilayah geografis tertentu karena ada ikatan pada asal-usul leluhur, adanya hubungan yang kuat dengan sumber daya pesisir dan Pulau-Pulau Kecil, serta adanya sistem nilai yang menentukan pranata ekonomi, politik, sosial dan hukum. bandingkan dengan definisi Pengertian Masyarakat Hukum Adat pada huruf 33 Pasal 1 Ketentuan Umum UU No 27 tahun 2007

16 Lihat Peter Burns dalam Tulisannya Adat, Yang Mendahului Semua Hukum pada Jamies S. Davidson, David Henley, Sandra Moniaga (ed), Adat Dalam Politik Indonesia, Yayasan Pustaka Obor Indonesia; KITLV-Jakarta, Jakarta, 2010, hlm 77

17 Ibid. 
dengan manusia, manusia dengan alam maupun manusia dengan "Yang Maha Ghaib". Ketertiban yang diciptakan untuk kebersamaan dalam komunitas adat itu sendiri maupun terhadap yang lain. Fungsi hukum adat ini semestinya benar-benar diakui eksistensinya dalam tatanan masyarakat adat itu sendiri. Keberlakuan hukum adat kiranya menjadikan harmoni dan selaras bersama hukum nasional, melalui Pasal 28D ayat (1) yang menjadikan dasar hak asasi masyarakat adat dalam memberlakukan hukum adatnya masing-masing dengan menjaga agar hukum nasional tidak menindas hukum adat dan hukum adat tidak bertentangan dengan nilai-nilai konstitusional peraturan perundangundangan dari negara. ${ }^{18}$

Pasal 1 ayat (3) UUD NRI Th 1945 menyebutkan Indonesia adalah negara hukum, maka hukum adat hendaknya menjadi bagian dari hukum yang ada di indonesia, hanya saja keberlakuanya bersifat terbatas, terbatas daerah atau kelompok tertentu dan yang masih relevan dengan kepantasan sesuai hukum nasional.

Menurut Agama Islam yang disebutkan dalam kaidah fiqh ${ }^{19}$, Penetapan hukum berdasarkan alasan adat juga mendapatkan landasan teori fiqh yang cukup banyak. Antara lain kaedah fiqh :"al 'Adah Muhakkamah, Ya'ni anna al 'adah 'ammah kanat aw khasshah tuj'al hukman li Itsbat hukm syari'y" (adat ataupun tradisi dapat dijadikan suatu dasar untuk menjadikan atau menetapkan sebagai hukum syara'/agama) atau kaedah $A l$ Tsabit bi al Urf ka al Tsabit bi al Syar' (ketetapan yang didasarkan atas tradisi sama dengan ketetapan yang didasarkan atas syara') atau isti'mal an-nâs hujjatun yajibu al'amal bihâ (Kebiasaan masyarakat yang banyak adalah dasar hukum yang harus diikuti sebagai hukum). Tentunya kaedah fiqih tersebut hendaknya sesuai dengan kaidah dan prinsip-prinsip beragama, dan bernegara atau maqashid al syari'ah. Ini menunjukkan hukum adat pun diakui oleh Islam dengan persyataran yang ditentukan yakni tidak bertentangan dengan nilai-nilai Islam. ${ }^{20}$

Dalam Islam dijelaskan bahwa manusia yang dicptakan terdiri dari suku, berbangsabangsa, saling berlainan kulit, bahasa dan yang lainnya, sehingga tata cara, budaya yang berbeda-beda sudah telah disebutkan dalam surat Arrum ayat 22 dan Hujjarat ayat $13 .^{21}$

18 Ibid.

19 Kata Fiqh berasal dari bahasa Arab, faqiha - yafqahu-fiqhan, yang berarti al-fahmu (paham), yakni alfahmu ini adalah pemahaman orang, yang pada umumnya alim, baik secara individual maupun kolektif, terhadap sumber ajaran Islam (Al Quran dan Hadis) untuk memperoleh ketentuan hukum yang dibutuhkan umat Islam dalam kehidupan yang dihadapinya pada ruang dan waktu tertentu. Lihat Kata Pengantar Said Aqil Siradj dalam Marzuki Wahid, Fiqh Indonesia, Kompilasi dan Counter Legal Draft Kompilasi Hukum Indonesia dalam Bingkai Politik Hukum Indonesia, Bandung, Penerbit Marja, 2014 hlm. x

20 Lihat Husein Muhammad dalam Mengharap Terobosan Hukum Lebih Lanjut di Pengadilan Agama? http://www.komnasperempuan.or.id/2008/12/mengharap-terobosan-hukum-lebih-lanjut-di-pengadilanagama/ diakses pada 28 Januari 2015

20 Lihat Qur'an Surat Ar-Rum ayat 20 dan Surat Hujjarat ayat 13 yang menunjukkan bahwa Allah Ta'ala menciptakan dalam keadaan bersuku-suku, perbedaan bahasa, warna kulit dan yang lainnya.

21 Lihat Qur'an Surat Ar-Rum ayat 20 dan Surat Hujjarat ayat 13 yang menunjukkan bahwa Allah Ta'ala menciptakan dalam keadaan bersuku-suku, perbedaan bahasa, warna kulit dan yang lainnya. 
Keberadaan masyarakat adat diatur dalam konstitusi dan hak-hak masyarakat adat juga diatur dalam konstitusi, namun keberadaan masyarakat adat belum tertuang dengan jelas definisi dan pengaturannya, jika melihat pada Pasal 18B ayat (2) UUD NRI Tahun 1945 keberadaan masyakarat adat bersifat limitatif atau bersyarat, sehingga pengakuannya belum secara utuh, apalagi keberadaan undang-undang masyarakat adat hingga kini masih belum terwujud.

Dalam disertasinya, A. Sodiki menyebutkan menurut pasal tersebut, negara mempunyai peranan penting dalam hal menguasai dan mempergunakan bumi dan air dan kekayaan yang terkandung di dalamnya secara maksimal. Dalam hal ini dibicarakan tugas dan wewenang negara memajukan kesejahteraan rakyat yang secara teoritik negara menganut konsep negara kesejahteraan (welfare state). ${ }^{22}$

Dalam negara kesejahteraan, individu dan masyarakat adat diakui hak-haknya sekalipun terbatas atas bumi air serta kekayaan di dalamnya. Sebagaian masyarakat Indonesia yang berada di wilayah pesisir, kepemilikan dan tempat tinggal yang ditempati masyarakat adat merupakan bagian dari Pasal 27 ayat (2) UUD NRI Tahun 1945 dan menjaga keberlangsungan masyarakat adat seperti yang tertuang dalam Pasal 28I ayat (3) UUD NRI Tahun 1945.

Negara hukum dalam perkembangannya senantiasa dipautkan dengan konstitusi negara, terutama dalam pengaturan penegasan tentang pembatasan kekuasaan negara untuk menjamin kemerdekaan dan hak-hak dasar warga negara dan perlindungan-nya. Meskipun tidak semua negara yang memiliki konstitusi diilhami oleh semangat individualisme, namun semangat untuk melindungi individu dan warganya melalui konstitusi dianggap paling memungkinkan, terlepas dari falsafah-falsafah negara yang bersangkutan. Dengan kata lain esensi dari negara berkonstitusi adalah perlindungan terhadap hak-hak asasi manusia. Atas keberadaan konstitusi dalam suatu negara merupakan (kemutlakan) conditio sine quanon. ${ }^{23}$

Hamid S. Attamimi merujuk pada pandangan Burkens, mengatakan bahwa negara hukum (rechtstaat) secara sederhana adalah negara yang menempatkan hukum sebagai dasar kekuasaan negara dan penyelenggaraan kekuasaan tersebut dalam segala bentuknya dilalkukan di bawah kekuasaan hukum. ${ }^{24}$ Sehingga dalam bertindak, negara bertindak berdasarkan atas aturan atau hukum yang ada, dalam hal ini peraturan perundangundangan.

Di lingkungan masyarakat pesisir, nelayan tradisional adalah kelompok yang paling menderita, miskin dan seringkali merupakan korban proses marginalisasi akibat kebijakan modernisasi perikanan. Secara umum, yang disebut nelayan tradisional adalah nelayan yang memanfaatkan sumber daya perikanan dengan peralatan tradisional, modal

22 Mengenai pengertian dan pemaknaan kata "Menguasai"akan dibahas selanjutnya

23 Lihat Nurul Qomar, Hak Asasi Manusia Dalam Negara Hukum Demokrasi, (Jakarta: Sinar Grafika, 2013), hlm. 26

24 Lihat Ibid., 
usaha yang kecil, dan organisasi yang relatif sederhana. Dalam kehidupan sehari-hari, nelayan tradisional lebih berorientasi pada pemenuhan kebutuhan sendiri (subsistence). Dalam arti hasil alokasi tangkapan yang dijual lebih banyak digunakan untuk memenuhi kebutuhan pokok sehari-hari, khususnya pangan, dan bukan untuk diinvestasikan kembali untuk pengembangan skala usaha. ${ }^{25}$

Keadaan masyarakat nelayan tradisional maupun masyarakat adat di wilayah pesisir atau di desa-desa pantai umumnya memiliki kesejahteraan hidup yang rendah dan tak menentu. Keadaan kesulitan dalam memenuhi kebutuhan hidup sehari-hari dan kemiskinan di desa-desa pantai telah menjadikan penduduk di kawasan ini menanggung beban kehidupan yang berat. ${ }^{26}$ Masyarakat adat di wilayah pesisir ataupun pulau-pulau kecil pun mengalami nasib yang sama yakni "keterasingan" masyarakat dalam menikmati hasil pembangunan yang berkeadilan, dalam hal pengelolaan sumber daya pesisir dan laut pun demikian, banyaknya investor asing yang datang dan menjadikan mereka terusir dari daerahnya.

Perkembangan pembangunan hendaklah berwawasan pembangunan berbasis lingkungan yang berkelanjutan, dalam hal ini pembangunan dalam sektor lingkungan kemaritiman, contoh permasalahan yakni terjadinya pendangkalan yang serius di perairan Teluk Kendari akibat sediman yang masuk melalui aliran sungai yang hulu dan daerah aliran sungainya di Kabupaten Konawe dan Konawe Selatan. Sepanjang aliran sungainya terdapat pemukiman masyarakat, aktivitas pertanian, perkebunan dan juga pertambangan. Perairan Teluk Kendari merupakan perairan semu tertutup mengalami pendangkalan hingga mencapai $30 \%$ dari luas wilayahnya dan disebabkan belum adanya aturan pengelolaan sungai. Kerusakan ini juga disebabkan oleh faktir pembangunan dan pertambang dengan rusaknya hutan bakau yang beralih fungsi, dan sedimen yang menjadikan rusaknya ekosistem koral sehingga mengancam keberadaan ekosistem ataupun ikan-ikan maupun biota yang hidup di perairan Teluk Kendari. ${ }^{27}$

Kerusakan ekosistem pesisir menjadikan salah satu faktor terjadinya kemiskinan dan kesenjangan ekonomi dan pembangunan yang berkelanjutan, sehingga banyak ditemui nelayan tradisional dan nelayan dari masyarakat adat kesulitan mencari ikan karena faktor kerusakan lingkungan.

Keberadaan undang-undang mengenai bidang kemaritiman terbagi di berbagai perundang-undangan sektoral yang mengatur hal-hal yang terkait pada pemgaturan kemaritiman, baik perikanan, kelautan dan ekplorasi sumber daya alam. Perlunya undang-undang pengelolaan wilayah pesisir yang kemudian melahirkan UU No 27 Tahun 2007 yang dalam perkembangannya mengalami perubahan akibat terjadinya uji materiil yang disebabkan materi muatan yang terkandung dalam UU No 27 Tahun 2007 melanggar hak konstitusional masyarakat pesisir itu sendiri.

Bagong Suyanto, “Anatomi Kemiskinan dan Strategi Penanganannya”, Intrans, Malang 2013, hlm 59-60 
Laut merupakan salah satu tempat yang sangat stategis, dalam buku yang berjudul Ocean Politics in Southeast Asia tulisan Peter Polomka pada tahun 1978, kajiannya menitikberatkan pada masalah kelautan yang berkembang dalam Konferensi Hukum Laut Internasional ke III, khususnya perkembangan di Asia Tenggara, yang menurutnya laut menjadi pusat perhatian negara-negara bangsa (nation states) dan perusahaan transnasional untuk memperoleh kekayaan, kekuasaan dan prestise. Laut menjadi isu dasar dalam saling ketergantungan antarnegara, serta stabilitas dan kemakmuran global dalam jangka panjang, karena eksploitasi lautan oleh beberapa pihak menimbulkan masalah kontemporer seperti politik, hukum, ekonomi, lingkungan dan teknologi. ${ }^{28}$

Akibat dari kelautan yang menjadi perhatian negara-negara bangsa, maka kelautan berhuhungan dengan perbatasan antar negara, dan juga multi negara yang berbatasan dengan laut dimana batas diukur dari wilayah pesisir atau daratan terluar yang kaitannya dengan perbatasan darat juga. Perlunya pengaturan dan perjanjian internasional yang diratifikasi oleh negara agar menjadi bagian perlindungan bagi rakyatnya dalam mengakses lautan untuk dieskploitasi, khususnya masyarakat adat pesisir maupun nelayan tradisional. Dalam UNCLOS 1982 hak-hak nelayan tradisional diakui keberadaannya, sehingga ada "perlakuan khusus" untuk nelayan tradisional. ${ }^{29}$

Keberadaan UNCLOS 1982 yang mengatur mengenai keberadaan traditional fishing right menjadikan rujukan pemerintah membuat pengaturan dalam mengaplikasikan hak tersebut. Hak Penangkapan Ikan Tradisional (traditional Fishing Right) yang dalam perkembangannya masih terdapat perbedaan pengertian, yakni ada yang menginterpretasikan Tradisional Fishing Right sebagai hak penangkapan ikan tradisional dan ada pula yang menginter-pretasikannya dengan hak tradisional atas perikanan.

Hasyim Djalal berpendapat yang mengatakan bahwa concept of tradisional fishing rigt should be clearly distinguised from the concept of traditional rigt to fish. Tradisional right to fish atau hak tradisional atas perikanan dilaksanakan di laut lepas berdasarkan kebebasan di laut lepas yang telah diatur dalam rezim hukum laut lepas. Sedangkan tradisional fishing right didasarkan pada bagian laut yang berada di bawah yurisdiksi negara pantai, yaitu pada perairan kepulauan dan pada ZEE. ${ }^{30}$

Perlindungan nelayan tradisional (adat) perlu dilakukan terkait yang terkait langsung dengan keberadaan hak tradisional penangkapan ikan ini, dan yang bersentuhan langsung dengan perbatasan dengan negara lain, seperti yang telah terjadi penangkapan nelayan tradisional masyarakat NTT oleh pemerintah Australia, seperti yang diungkap dalam tulisan Ira Wati dan Oentong Wahjoe, terkait ditangkapnya 49 nelayan Indonesia yang berasal dari Ndao, Flores pada 2005 dan 230 orang yang ditangkap oleh kapal patroli

28 Lihat Syamsumar Dam, Politik Kelautan, Bumi Aksara, Jakarta, 2010, hlm. 1-2

29 Lihat Pasal 51 dan 53 ayat (3) UNCLOS 1982 mengenai hak nelayan tradisional

30 Lihat, Irawati, Oentoeng Wahjoe, Tanggung Jawab Negara dalam Melindungi Hak Nelayan Tradisional Indonesia di Perairan Australia, Jurnal Mimbar: Volume XXVII, No. 1, Juni 2011, Universitas Islam Bandung, hlm. 13 
Australia di wilayah perairan kepulauan karang Ashmore pada 2007 dan ditahan di pusat penahanan (detention center) Darwin, dan terjadi kembali di tahun 2008. Seperti yang diketahui bahwa nelayan tradisional ataupun masyarakat adat pesisir yang menjadi nelayan telah melakukan penangkapan jauh sebelum terbentuknya pemerintahan Australia, dan hak nelayan tradisional diakui oleh UNCLOS 1982 yang kemudian Indonesia juga mempunyai hak melakukan penangkapan ikan di bagian tertentu di perairan Australia, hal ini tertuang dalam memorandum of Understanding bertween the Goverment of Australia and the Goverment of the Republic of Indonesia Regarding of operation of Indonesia Traditional Fisherment in the area of the Australia Exclusive Fishing zone and Continental Shelf (MoU Box 1974) yang dalam perkembangannya pada 2 Maret 1989 sepakat melakukan perjanjian terkait pelaksanaan Agreed Miniutes of Meeting Between Official of Indonesia and Australia on Fisheries 1989 yang tertuang dalam Annex. ${ }^{31}$

Keberadaan suku-suku laut atapun masyarakat adat pesisir yang menjadi nelayan dengan peluang melampaui batas negara karena asal usul dari hak nelayan tradisional, maka negara harus memberikan perlindungan hukum, HAM dan kearifan lokal. Undangundang yang bersinggungan dengan ini adalah perjanjian bilateral mengenai batas negara, yang mengatur berbagai batas negara Indonesia dengan negara lain yang terdapat teritorial laut oleh nelayan tradisional dalam menangkap ikan dengan melakukan perjanjian yang diratifikasi. Sehingga ada kepastian hukum dalam perlindungan masyarakat adat sesuai pasal 28D ayat (1) UUD NRI Tahun 1945 sebagai bagaian perlindungan hukum, Pasal 28D ayat (2) UUD NRI tahun 1945 untuk bekerja dan mendapat hasilnya ${ }^{32}$ serta ketentuan yang tertuang dalam Pasal 27 ayat $(2)^{33}$ yang menjamin tiap-tiap warga negara mendapat pekerjaan dan penghidupan yang layak, baik itu yang dilakukan oleh masyarakat adat maupun nelayan lokal yang merupakan subjek warga negara.

Nelayan tradisional ataupun nelayan dari masyarakat adat di Indonesia yang hidupnya sebagai "manusia perahu" atau masyarakat adat yang nomaden seperti suku Bajo perlunya perlindungan hukum disaat masyarakat Suku Bajo yang hidupnya di wilayah perairan yang biasa melaut hingga melewati perbatasan negara, jika melewati batas negara tetangga tentunya melanggar yuridiksi negara lain dan dimungkinkan untuk ditangkap seperti terjadinya penangkapan nelayan pembudidaya rumput laut yang ditangkap oleh Polisi Diraja Malaysia di perbatasan Nunukan, Kalimantan ${ }^{34}$ akibat batas wilayah laut merupakan batas wilayah "semu" yang tidak nampak tandanya, dan nelayan adat ataupun nelayan tradisional yang secara turun temurun melakukan penangkpan ikan yang di wilayah yang bisa melewati batas negara lain, dan kasus semacam ini perlu

31 Ibid.,

32 Dalam Pasal 28D ayat (2) menyebutkan sebagai"bekerja” dan mendapat “imbalan" yang merupakan apa yang didapatkan, baik dari usaha sebagai nelayan maupun sebagai buruh.

33 Lihat Pasal 27 ayat (2) UUD NRI Tahun 1945

34 Baca Nelayan Rumput Laut Terancam Hukuman di Malaysia <http://www.beritasatu.com/nasional/250888nelayan-rumput-laut-terancam-hukuman-di-malaysia.html> 
adanya kehadiran negara dalam melindungi warga negaranya, agar tidak serta merta ditangkap maupun diusir.

Perlindungan hukum dalam konteks hubungan bilateral antar negara dalam perlindungan untuk masyarakat adat yang berada di laut, hal ini sesuai dengan kaidah hukum Laut Internasional yang telah disepakati banyak negara, termasuk oleh Indonesia dan negara yang berbatasan langsung di laut. ${ }^{35}$ Hingga saat ini Indonesia membuat perjanjian mengenai perlindungan nelayan adat atau tradisional hanya dengan Australia untuk melindungi masyarakat adat atau nelayan tradisional agar tidak serta merta ditindak sesuai hukum di laut teritorial ataupun ditangkap. Perjanjian ini mencakup wilayah yang secara tradisional ataupun turun temurun menjadi tempat menangkap ataupun mengeksploitasi laut secara tradisional.

Selaras pandangan HAM menurut ajaran Islam, pada Surat Al Isro ayat 70 disebutkan Dan sungguh, Kami telah memuliakan anak cucu Adam, dan Kami angkut mereka di darat dan di laut, dan Kami beri mereka rejeki dari yang baik-baik, dan Kami lebihkan mereka di atas banyak makhluk yang Kami ciptakan, dengan kelebihan yang sempurna. ${ }^{36}$ Dalam tafsir Al Misbah menyebutkan bahwa ayat ini merupakan pandangan Islam tentang HAM, manusia siapapun harus dihormati tanpa perbedaan. Semua memiliki hak hidup, hak bicara, hak mengeluarkan pendapat, hak beragama, hak memeroleh pekerjaan dan berserikat dan lain-lain dicakup oleh deklarasi HAM dengan batasan hak-hak dimaksud adalah anugerah Allah sebagaimana dipahami dari kata karramna/kami muliakan dan dalam koridor tuntunan Agama Nya. ${ }^{37}$ Menurut Mohammad Hasbi Ash-Shidieqy ${ }^{38}$ menyimpulkan dari ayat tersebut bahwa anugerah Tuhan tidak memandang latar belakang etnis, agama, dan aspirasi politik, ketiga kemuliaan tersebut adalah 1 . Kemuliaan pribadi (karamah fardiyah) dalam arti Islam memelihara kepribadian maknawi dan kepribadian materiil (maddy) manusia; 2. Kemuliaan Masyarakat (karamah ijtimaiyah), di dalam status persamaan manusia dijamin sepenuhnya; dan 3. Kemuliaan Politik (karamah siyasiyah), Islam memberikan semua hak-hak politik kepada manusia untuk memilih dan dipilih bagi posisi-posisi politik karena ia adalah khaliah Tuhan di bumi. ${ }^{39}$

Selaras dengan hal tersebut menunjukkan bahwa terdapat fleksibilitas nilai-nilai Islam dalam menjamin HAM untuk semua makhluk manusia sehingga tidak sepihak dalam memberikan perlindungan dan mencapai kesejahteraan manusia dan dengan

35 Lihat Pasal 51 dan Pasal 62 ayat (2) UNCLOS 1985 mengenai Hak Penangkapan Ikan Tradisional (Traditional Fishing Right)

36 Lihat QS 17 Al Isro' 70

37 Lihat M. Quraish Shihab, Tafsir Almisbah: Pesan, Kesan dan Keserasian Al Quran, vol.7 Lentera Hati, Jakarta, 2002, hlm 151-152

38 Mohammad Hasbi Ash-Shidieqy Lahir 10 Maret 1904, Wafat 9 Desember 1975 merupakan tokoh Masyumi yang mendasarkan teori atas Al Quran ajaran Islam klasik, Lihat Ahamad Syafii Maarif, Islam dan Pancasila Sebagai Dasar Negara: Studi tentang Perdebatan dalam Konstituante, LP3ES, Jakarta, 2006, hlm. 170-171

39 Ibid., 171-172 
memuliakannya. Masyarakat adat yang hidup merupakan yang salah satu kelompok minoritas yang juga keberadaannya telah ada sebelum adanya negara berdiri.

Dalam teori keadilan sosial Islam menjamin dengan prinsip kebebabasan jiwa, persamaan kemanusian dan jaminan sosial. Dalam konsep kebebasan jiwa adalah bagaimana menjadikan manusia berlaku tidak berlebih dalam mengeksploitasi sumber daya alam, "Katakanlah siapakah yang mengharamkan perhiasan dari Allah yang telah dikeluarkan-Nya untuk hambah-hambahNya, dan (siapakah yang mengharamkan) rejeki yang baik..." 40 "...dan janganlah kamu melupakan bagianmu dalam kenikmatan dunia ini.." 41 mengeksploitasi sumber daya alam dengan batasan yang wajar dan tanpa keserakahan, hal ini tidak nampak pada UU no 27 Tahun 2007 yang membatasi masyarakat adat di pesisir dalam mengeksploitasi sumber daya alam seakan masyarakat yang sudah ada jauh sebelum negara berdiri dan mereka diminta untuk memperoleh sertifikat HP-3 tentunya tidak sesuai dengan semangat keadilan.

Islam menjamin kebebasan jiwa dengan kebebasan penuh yang tidak ditunjukkan secara maknawiah saja atau ekonomi melainkan juga keseluruhan. Tanpa adanya kebebasan jiwa individu maka akan tidak tercapai bagaimana mendapatkan dan memberikan keadilan. ${ }^{42}$

Persamaan kemanusiaan, prinsip kemanusiaan dalam hal ini sangat terkait dengan hak asasi manusia agar setiap manusia terbebas dari penderitaan, kemiskinan dan kehinaan, dan menjaga dari tekanan dari pihak lain dari aspek kebendaan. Untuk itulah hak masyarakat adat harusnya mendapatkan haknya bertempat tinggal tanpa "diganggu" oleh pembangunan wilayahnya dengan pembangunan daerah yang justru menjadikan terpinggirkannya masyarakat adat itu sendiri.

Pembangunan untuk mencapai keadilan sosial berdasarkan hak asasi seperti yang tertuang dalam Pasal 28H ayat (1) UUD NRI Tahun 1945 yang menjamin masyarakat hidup sejahtera, bertempat tinggal dan mendapatkan lingkungannya yang baik. Baik dalam hal ini bukan sekedar dalam perspektif pembangunan melainkan bagaiamana kenyamana masyarakat.

Seperti yang terjadi pada masyarakat adat Bajo di wilayah pesisir Desa Torosiaje, Desa Torosiaje Raya, mereka mau dibangun jembatan beton dan jalan beraspal namun tidak mau sampai pada pemukiman mereka, karena akan masuk motor dan kendaraan yang menyebabkan kebisingan dan asal serta hal lain yang merugikan. ${ }^{43}$ Tentunya pembangunan bukan sekedar pembangunan fisik melainakna bagaimana ketenangan batin masyarakat seperti kaidah kebebasan jiwa.

40 Lihat QS 7 ayat 32

41 Lihat QS 28 ayat 77

42 Lihat Sayyid Qutbh, al-'Adalah al Ijtimah'iyyah fil-Islam, Dar al-Katib al-'Araby, Cairo, tt diterjemahkan Afif Mohammad, Keadilan Sosial Dalam Islam, Penerbit Pustaka, Bandung, 1984, hlm. 60-63

43 Lihat Kearifan Suku Bajo Menjaga Kelestarian Pesisir dan Laut < http://www.mongabay.co.id/2014/01/26/kearifan-suku-bajo-menjaga-kelestarian-pesisir-dan-laut/> diakses pada 31 Desember 2014 
Jaminan sosial sebagai konsep yang ketiga dalam keadilan sosisal dalam Islam, memberikan jaminan bagaimana memberikan kesejahteraan masyarakat pesisir agar terjamin kesejahteraannya, masyarakat adat melakukan eksplorasi alam dengan cara tradisional dan dengan pengetahuan kecerdasan ekologis (ecological intellegence). Kecerdasaan ekologis adalah bagaimana cara melakukan eksplorasi sumber daya alam di wilayah pesisir dan laut dengan mendekati dan bersatu dengan alam. Hal ini lazim terjadi pada masyarakat adat, seperti ciri masyarakat adat bercorak magis-religius yakni dengan percaya hal-hal gaib.

Jika kita melihat masyarakat modern juga masih percaya hal magis-religius yang tertuang dalam undang-undang, dengan kalimat "Dengan Rahmat Tuhan Yang Maha Esa" yang biasa tertuang dalam konsideran perundang-undangan, tujuannya adalah agar perturan perundang-undangan tersebut dapat diaplikasikan dengan baik. ${ }^{44}$

Nilai-nilai ketuhanan merupakan bagian dalam jaminan sosial, dimana negara menjamin kesejateraan masyarakat adat. Melalui usaha dalam memberdayakan masyarakat adat pesisir tersebut, bukan sekedar untuk menjadikan kepemilikan pribadi seperti adanya HP-3.

Kerusakan wilayah pesisir tidak disebabkan kerusakan di wilayah pesisir dan akibat ekplorasi laut, hal ini disebabkan oleh kerusakan di darat, yang disebabkan pencemaran. Forum Global tentang Kelautan, Pesisir dan Pulau-pulau (The Global Forum on Oceans Coast an Island) telah mengangkat isu perlindungan laut dan kegiatan di daratan. Kerusakan ekosistem dan sumber daya pesisir dan laut akan mempunyai dampak luas kepada berbagai kehidupan manusia, tentunya terhadap masyarakat adat di pesisir. ${ }^{45}$

Dalam Al Quran Surat Al A'Raf disebutkan "Dan janganlah kamu membuat kerusakan di muka bumi, sesudah (Allah) memperbaikinya dan berdoalah kepada-Nya dengan rasa takut (tidak akan diterima) dan harapan (akan dikabulkan). Sesungguhnya rahmat Allah amat dekat kepada orang-orang yang berbuat baik" ${ }^{, 46}$ kerusakan di bumi dilakukan oleh manusia itu sendiri, diayat lain Allah Ta'ala berfirman Telah nampak kerusakan di darat dan di laut disebabkan karena perbuatan tangan manusia, supaya Allah merasakan kepada mereka sebahagian dari (akibat) perbuatan mereka, agar mereka kembali (ke jalan yang benar) ${ }^{47}$ untuk itulah negara berperan aktif dalam membuat regulasi. Karena negara menguasai kekayaan dan sumber daya di negara ini, sedangkan konsepsi menguasain dalam arti Bahwa mengenai konsep Penguasaan Negara di dalam pertimbangan hukum putusan Mahkamah Konstitusi perkara Undang-Undang Minyak dan Gas, Undang-Undang Ketenagalistrikan, dan Undang-Undang Sumber Daya Alam, menafsirkan mengenai "Hak Menguasai Negara/HMN" bukan dalam makna

44 Lihat, Hilman Hadikusumah, Pokok-pokok Pengertian Hukum Adat, Penerbit Alumni, Bandung, 1980, hlm 53

45 Lihat Endang Bidayani, Ekonomi Sumberdaya Pesisir yang Tercemar, UB Press, Malang, 20114, hlm.5152

46 Lihat QS Al a'Raf 7 ayat 56

47 Lihat QS Ar-Rum ayat 41 
negara memiliki, tetapi dalam pengertian bahwa negara merumuskan kebijakan (beleid), melakukan pengaturan (regelendaad), melakukan pengurusan (bestuurdaad), melakukan pengelolaan (beheersdaad), dan melakukan pengawasan (toezichthoudendaad); Dengan demikian, makna penguasaan negara terhadap cabang-cabang produksi yang penting dan menguasai hajat hidup orang banyak, serta terhadap sumber daya alam, tidak menafikan kemungkinan perorangan atau swasta berperan asalkan lima peranan negara/pemerintah sebagaimana disebut di atas masih tetap dipenuhi dan sepanjang pemerintah dan pemerintah daerah memang tidak atau belum mampu melaksanakannya;

Bahwa meskipun kelima peranan negara/pemerintah tersebut di atas telah terpenuhi, harus tetap diingat bahwa tujuan dari penguasaan negara adalah sebesar-besarnya untuk kemakmuran rakyat. Sehingga harus dapat dipastikan/dijamin bahwa lahirnya suatu undang-undang yang bersinggungan dengan kewajiban negara untuk mensejahterakan rakyat terkait dengan cabang-cabang produksi maupun sumber daya alam tidak menimbulkan kesalahan fatal di dalam pelaksanaannya. ${ }^{48}$

Perlu perumusan kebijakan yang menyeluruh dan lintas sektoral, untuk menjadikan perlindungan pada masyarakat adat di wilayah peisisir dari kerusakan lingkungan. Untuk mencapai kesejahteraan sosial, jaminan sosial dalam Islam bukanlah pemberian asuransi atau uang secara Cuma-Cuma, melainkan memberdayakan agar masyarakat adat dapat bekerja dan memenuhi kebutuhannya secara proporsional dan tidak diganggu oleh orang lain. Jika menurut Spicker dalam mencapai usaha kesejahteraan sosial harus memcakup bidang kesehatan, pendidikan, perumahaan, jaminan sosial dan pekerjaan sosial. ${ }^{49} \mathrm{Hal}$ itu merupakan bagian dari jaminan sosial dalam Islam.

Melihat perspektif UU No 27 Tahun 2007 akan nampak jelas bahwa pembangunan pesisir diperlukan sehingga harus adanya sertifikasi dalam pemanfaatan wilayah peisir di dasar dan permukaan laut, ini sangat tiak sesuai dengan keadilan. Dalam perubahan UU No 27 Tahun 2007, yang tertuang pada UU No 1 Tahun 2014 memang menjadikan masyarakat adat subjek dalam pembangunan, namun belum tersentuh pembanguan di darat yang merusak lingkungan.

Dalam ketentuan Pasal 20 UU No 1 Tahun 2014 belum sepenuhnya berpihak kepada masyarakat adat yang menurut penulis masyarkat adat merupakan masyarakat tradisional, dimana masyarakat adat tentu menggunakan kaidah kearifan lokal dalam pengelolaan wilayahnya maupun dalam pemenuhan kebutuhan, berbeda dengan masyarakat lokal yang beromisili pada suatu tempat dan belum tentu menggunakan alat tangkap tradisonal yang berbasis kerarifan lokal. ${ }^{50}$ Jika dalam pemanfaatan ruang dan sumber daya perairan pesisir dan pulau kecil memerlukan izin, tentunya demikian bukanlah perlindungan terhadap masyarat adat, harusnya pemerintah bukan memfasilitasi melainkan

48 Lihat Putusan MK Nomor 3/PUU-VIII/2010

49 Lihat Isbandi Rukminto Adi, Kesejahteraan Sosial: Pekerjaan Sosial, Pengembangan Sosial dan Kajian Pembangunan) Suatu Pengantar, Rajawali Pres, Jakarta, 2013, hlm. 269-270

50 Lihat dan bandingkan definisi masyarat adat, masyarakat lokal dan masyarakat tradisional dalam ketentuan umum UU No 1 Tahun 2014 
memberikan perlindungan dalam pengelolaan wilayahnya dari kepentingan "pembangunan" yang dapat merusak tatanan kearifan lokal pada masyarakat adat.

Pengelolaan wilayah pesisir laut dan pengelolaan pulau-pulau opsi doktrin Mare Liberum atau laut bebas yang dicetuskan oleh Hugo de Groot atau kita kenal dengan Hugo Grotius yang merupakan ahli hukum di Belanda, yang kemudian berkembangan menjadi rejim pemanfaatan sumber daya laut menjadi rezim akses terbuka, sehingga dengan keberadaan rejim ini menjadikan perlunya pemerintah mengatur suatu peraturan dengan membentuk aturan yang hingga level bawah. ${ }^{51}$

Konsep keadilan yang pada prinsipnya berarti pemberdayaan kaum miskin/lemah untuk memperbaiki nasib mereka sendiri dalam sejarah manusia yang terus mengalami perubahan sosial. Secara umum, Islam memperhatian susunan masyarakat yang adil dengan membela nasib mereka yang miskin/lemah, seperti terlihat pada ayat suci berikut; “Apa yang dilimpahkan (dalam bentuk pungutan fa'i) oleh Allah atas kaum (penduduk sekitar Madinah), maka harus digunakan bagi Allah, utusan-Nya, sanak keluarga terdekat, anak-anak yatim, orang-orang miskin, para peminta-minta/pengemis dan pejalan kaki di jalan Allah. Agar supaya harta yang terkumpul itu tidak hanya berputar / beredar di kalangan orang-orang kaya saja di lingkungan kalian". (Ma Afaa-a Allahu 'ala rasulihi min ahl al-qurra fa li-Allahi wa li al-rasul wa li dzil al-qurba wa al-yata wa al-masakin wa ibn al sabil, kaila yakuuna dulatan bain al-aghniya minkum). Konsep keadilan menurut Islam ini berlaku untuk pengelolaan wilayah pesisir, sehingga hak-hak masyarakat adat tetap terjaga. Konsep keadilan sosial dalam islam adalah sama rata dan sama merasakan, yakni merasakan dari porsi yang telah ada dengan usaha dan kemampuannya. Sehingga melarang berlaku tidak adil dengan menguasai wilayah pesisir untuk sektor ekonomi tanpa melihat keberadaan masyarak yang mendapatkan kehidupan dari daerah tersebut.

Sejalan dengan konsep keadilan menurut Islam adalah sama rata dan sama rasa, yakni kedudukan yang sama di muka hukum, sehingga tidak ada perbedaan hukum bagi semua golongan, sejalan dengan negara hukum Indonesia yang mendudukan persamaan di muka hukum. sehingga tidak diperbolehkan mengabaikan masyarakat adat pesisir untuk pembangunan, yang implikasinya adalah ketidakadilan sosial.

\section{KESIMPULAN}

Dari uraian di atas dapat disimpulkan bahwa bahwa Negara masih terkesan melakukan pengabaian terhadap menjaga kearifan lokal dan masyarakat adat yang mengelola sumber daya kelautan melalui kearifan tradisional dan menjadikan pembangunan cara modern sebagai solusi untuk meningkatkan pambangunan ekonomi dalam sector besar, bukan kesejahateraan dan keadilan untuk masyakat tradisional yang berkelanjutan baik ekosistem lingkungan maupun kesejahteraan sosial masyarakat. Pengakuan masyakat adat mutlak diperlukan untuk memberikan keududukan yang kuat dalam pengelolaan pesisir oleh masyakat adat.

51 Lihat dan Baca kesaksian saksi ahli dari wakil pemerintah Abdon Nababan 
Negara harus mempuat produk hukum yang tegas dalam memberikan perlindungan kepada masyarakat adat untuk meningkatkan kesejahteraan dan menjadikan terjaganya lingkungan ekosistem, kepastian hukum adalah cara perlindungan Negara terhadap masyarakatnya, agar tercipta keadilan dan kesejahteraan bagi masyarakatnya.

\section{DAFTAR PUSTAKA}

\section{Buku}

A. Hamid S. Atamimi, Peranan Keputusan Presiden Republik Indonesia Dalam Penyelengaran Negara, Suatu Studi Analisis Mengenai Keputusan Presiden Yang Bersfungsi Pengaturan Dalam Kurun Waktu Pelita I-Pelita IV, Disertasi, Jakarta: Fakultas Pasca Sarjana UI, 1990

Abdul Hakim G. Nusantara, Politik Hukum Indonesia, Jakarta: Yayasan Lembaga Bantuan Hukum Indonesia, 1998

Abdurahman, Hukum Adat Menurut Perundangan-Undangan Republik Indonesia, Jakarta, Cendana Press., 1984

Ahmad Erani Yustika, Negara vs Kaum Miskin, Yogyakarta: Pustaka Pelajar, 2003

Ahmad Syahrizal, Peradilan Konstitusi, Bandung, Pradya Paramita, 2006

As'ad Said Ali, Negara Pancasila Jalan Kemaslhatan Berbangsa, Pustaka LP3ES, Jakarta, 2009

Bagher Khorramshad Mohammad, Demokrasi Religius, RausyanFikr Institute, Yogyakarta, 2013

Bagir Manan, Teori dan Politik Konstitusi, cet. Kedua . Yogyakarta: FH UII Press, 2004

Bernard Arief Sidharta, Pengantar Logika, Sebuah Langkah pertama Pengenalan Medan Telaah, Refika Aditama, Bandung 2008

, Refleksi Tentang Struktur Ilmu Hukum, cet. II Bandung: Mandar Maju, 2000

Syamsumar Dam, Politik Kelautan, Jakarta: Bumi Aksara, 2010

H. Max Mulyadi Supangkat, Cakrawala Indonesia, Restu Agung, Jakarta, 2005

H.A.S Natabaya, Sistem Peraturan Perundang-undangan Indonesia, Jakarta: KonpresTatanusa, 2008

Hardiman, F Budi, Demokrasi Deliberatif, Penerbit Kanisius, Yogyakarta, 2009 
Gunawan Setiadiradja, Hak-Hak Manusia Berdasarkan Ideologi Pancasila, Kanisius, Yogyakarta, 1993

H.A.S Natabaya, Menata Ulang Sistem Peraturan Perundang-undangan Indonesia. Jakarta: Sekretaris Jenderal dan Kepaniteraan Mahkamah Konstitui, 2008

I Nyoman Nurjaya, Pengelolaan Sumber Daya Alam dalam Perspektif Antropologi Hukum, Prestasi Pustaka Publisher, Jakarta, 2008

Jimly Asshidiqqie, Konstitusi dan Konstitusionaliseme Indonesia, Jakarta: MKRI-Pusat Studi HTN FH UI, 2004

Jamine S. Davidson, David Henley, Sandra Moniaga (ed), Adat Dalam Politik Indonesia, Jakarta, Yayasan Pustaka Obor Indonesia; KITLV Jakarta, 2010

Jhon Griffiths, Memahami Pluralisme Hukum, Sebuah Diskripsi Konseptual, dalam Pluralisme Hukum Sebuah Pendekatan Interdisipliner, Penerjemah Andi Akbar dkk, Huma, Jakarta, 2005

C. Dewi Wulandari, Prof., Dr. S.H., M.H., S.E., MM, Hukum Adat Indonesia Suatu Pengantar, PT. Refika Aditya, Bandung, 2009

Lawrence M Friedman, Sistem Hukum Perspektif Ilmu Sosial (A Legal Sistem A Social Science Prespective), Diterjemahkan oleh M. Khozim, Nusa Media, Bandung, 2009

Lili Rasjidi, I.B. Wiyasa Putra, Hukum Sebagai Suatu Sistem, PT. Remaja Rodakarya, Bandung, 1993

M. Quraish Shihab, Tafsir Al Misbah Volume 2, Lentera Hati, Jakarta, 2002

M. Yamin, Tatanegara Majapahit, Yayasan Prapanca, Djakarta, 1962

Majid Khadduri, War and Peace in the Law of Islam, Baltimore and London, The John Hopkins Press, 1955

Muchin, Prof. Dr. S.H., Imam Koeswayono, S.H., M.Hum., Soimin, SH, Hukum Agraria Indonesia Dalam Perspektif Sejarah, PT. Refika Aditya, Bandung 2010

Muhammad Tahir Azhari, Negara Hukum Suatu Studi Prinsip-prinsip Dilihat dari Segi Hukum Islam, Implementasinya pad Periode Negara Madinah dan Masa Kini, Jakarta, Kecana, 2004

Nurul Qomar, Hak Asasi Manusia Dalam Negara Hukum Demokrasi, Jakarta: Sinar Grafika, 2013 
Oemar Seno Adji, Peradilan Bebas Negara Hukum, Erlangga, Jakarta

Padmo Wahyono, Membudayakan Undang-Undang Dasar 1945, Penerbit Ind. Hill., Jakarta, 1990

Patriani Siahaan, Politik Hukum Pembentukan Undang-undang Pasca Amandemen UUD 1945, Jakarta: Konstitusi Press, 2012

Peter Mahmud Marzuki, Penelitian Hukum, Kencana, Jakarta 2005

Puspoprodjo dan EK. T. Gilarso, Logika Ilmu Menalar, Dasar-Dasar Berpikir Tertib, Logis, Kritis, Analitis, Dialekti, Pustaka Grafika, Bandung 1999

Rachmat Syafaat, Rekonstruksi Politik Hukum Pangan Dari Ketahanan Pangan Ke Kedaulatan Pangan, UB Press, Malang, 2013

Ratno Lukito, Pergumulan Antara Hukum Islam Dan Adat Di Indonesia, Jakarta, INIS, 1998

Rohmin Dahuri, Pengelolaan Sumber Daya Wilayah Pesisir dan Lautan Secara Tercadu, Jakarta: cet-3 Pradnya Paramita, 2004

Sabian Utsman, Restorative Justice, Hukum Masyarakat Nelayan Saka dalam Sistem Hukum Nasional, Yogyakarta, Pustaka Pelajar, 2013

Satya Arinanto, Sejarah HAM dalam Prespektif Barat, Cesda LP3ES, Jakarta, 2000

M. Quraish Shihab, Tafsir Almisbah: Pesan, Kesan dan Keserasian Al Quran, vol.7, Jakarta: Lentera Hati, 2002

Slametmulyana, Nagarakretagama dan tafsir Sejarah, Bhratara karya Aksara, Jakarta, 1979,

Sulistyowati Irianto (edt), Hukum Yang Bergerak Tinjauan Antropologi Hukum, Yayasan Obor Indonesia, Jakarta

Sudargo Gautama, Pengertian Tentang Negara Hukum, Alumni, Bandung, 1973

Soepomo, Bab-Bab Tentang Hukum Adat, (Jakarta, Pradnya Paramita), 1983

Saafroedin Bahar, Nannie Hudawati (Penyunting), Risalah Sidang Badan Penyelidik Usahausaha Persiapan Kemerdekaan Indonesia (BPUPKI)-Panitia Persiapan Kemerdekaan Indonesia (PPKI) 28 Mei 1945-22 Agustus 1945,-cet. 1, edisi IV, Jakarta, Sekretariat Negara

Salim, Erlies Septiana Nurbani, Penerapan Teori Hukum Pada Penelitian Tesis dan Disertasi, Rajawali Pres, Jakarta, 2003 
Soepomo, Kedudukan Hukum Adat di Kemudian Hari, Jakarta, Pustaka Rakyat, 1952

Soerjono Soekanto, Kedudukan dan Peranan Hukum Adat di Indonesia, Jakarta, kurnia Esa, 1982

-----------, Teori Sosiologi Tentang Perubahan Sosial, 1984

, dan Sri Mamudji, Penelitian Hukum Normatif, Rajawali Pers, Jakarta, 1985

Soeripto, Hukum Adat dan Pancasila, Dalam Undang-Undang Pokok Kekuasaan Kehakiman, Jember, FH. Univ. Jember, (tt), hlm. 24

Surodjo Wignjodipuro, Pengantar dan Azas-azas Hukum Adat, Bandung, Alumni, 1973

Tahir Azhary, Negara Hukum, Jakarta, Bulan Bintang, 1992

Todung Mulya Lubis, Bantuan Hukum dan Kemiskinan Terstuktural, LP3ES, Jakarta, 1984

Yance Arizona (ed), Anatara Teks dan Konteks: Dinamika Pengakuan Hukum Terhadap hak Masyarakat Adat atas Sumber Daya Alam Di Indonesia, Jakarta, Huma, 2010

Makalah, Artikel, Jurnal

Pluralisme Hukum Sebagai Suatu Konsep Pendekatan Teoritos Dalam Perspektif Global, di sampaikan pada "Seminar Pluralisme Hukum dan Tantangan Bagi Pembentukan Sistem Hukum Nasional", kerjasama Badan Pembinaan Hukum Nasional DephumHAM, FH Universitas Hasanuddin, dam Kantor Wilayah Dephuk HAM Sulawesi Selatan, Makasar 1-2 Mei 2007

Kata Sambutan Ketua Komnas HAM pada Acara Hari Internasional Masyarakat Hukum Adat se Dunia, di Jakarta, 9 Agustus 2006 dalam Mewujudkan Hak Konstitusioan Masyarak Hukum Adat, Himpunan Dokumen Peringatan Hari Internasional masyarakat Adat Seduia, Komnas HAM Press, Jakarta

Rondald Z Titahelu, Masyarakat Adat dan Pembangunan, Menuju Keutuhan Makna Pembanguan Bagi Manusia dan Masyarakat Adat, Makalah Seminar, Pekanbaru, Oktober 1998

Berdayakan Masyarakat Hukum Adat untuk Perlindungan Lingkungan, diakses melalui http://www.hukumonline.com/detail.asp?id15257\&cl= berita pada 2 September 2013

Tatag Wiratno Pembangunan Wilayah Pesisir dan Laut Dalam Kerangka Pembangunan Ekonomi Daerah yang disampaikan pada Sosioalisasi Nasional Program MFCDP, 22 September 2004 di Jakarta 


\section{Tesis-Disertasi}

Saifudin, Proses Pembentukan UU: Studi Tentang Partisipasi Masyarakat Dalam Proses Pembentukan UU di era Reformasi, Disertasi. Jakarta: Fakultas Hukum Program Pasca Sarjana UI, 2006

\section{Undang-undang}

Undang-Undang Dasar Negara Republik Indonesia Tahun 1945

Undang-Undang Nomor 5 Tahun 1960 tentang Peraturan Dasar Pokok-Pokok Agraria

Undang-Undang Nomor 39 Tahun 1999 tentang Hak Asasi Manusia;

Undang-Undang Nomor 41 Tahun 1999 tentang Kehutanan;

Undang-Undang Nomor 7 Tahun 2004 tentang Sumber Daya Air;

Undang-Undang Nomor 32 Tahun 2004 tentang Pemerintahan Daerah; dan

Undang-Undang Nomor 26 Tahun 2007 tentang Penataan Ruang

\section{Internet}

http://www.indopos.co.id/2014/09/ruu-hukum-adat-terbengkalai-pansus-sayangkanpemerintah.html

http://www.beritasatu.com/nasional/250888-nelayan-rumput-laut-terancam-hukuman-dimalaysia.html

http://www.mongabay.co.id/2014/01/26/kearifan-suku-bajo-menjaga-kelestarian-pesisir-danlaut/

http://www.republika.co.id/berita/koran/khazanah-koran/15/05/13/noa0s821-pbnu-haramkaneksploitasi-alam-yang-merusak 